\title{
Determining the Relationship between Perceived Social Support Levels and Chemotherapy Symptoms in Women with Gynaecological Cancer
}

\author{
Jinekolojik Kanserli Kadınlarda Algılanan Sosyal Destek Düzeyleri ve \\ Kemoterapi Semptomları Arasındaki İlişkinin Belirlenmesi
}

(1) Sakine YILMAZ11, id Gülşen VURAL22

${ }^{1}$ Çankırı Karatekin University Faculty of Health Science, Çankırı, Turkey

${ }^{2}$ Yakın Doğu University Faculty of Nursing, Lefkoşa, KKTC

\begin{abstract}
Objective: Patients experience uncertainty and fear about what chemotherapy will bring as a cancer treatment. This uncertainty and fear often increase their need for social support. Social support, regardless of whether it is provided by family, peers or health staff, plays a crucial role in coping with chemotherapy. Social support functions as a buffer against conditions such chemotherapy symptoms. It also helps patients cope with stress caused by chemotherapy symptoms and increase their quality of life. This research aimed to determine the relationship between perceived social support levels and chemotherapy symptoms in women with gynaecological cancer.
\end{abstract}

Methods: The study was planned descriptively. The sample comprised 148 patients who were admitted to two public hospitals. Data were collected using the Chemotherapy Symptom Assessment Scale, the Multidimensional Scale of Perceived Social Support (MDSPSP) and a descriptive feature form. Data were analysed using the SPSS software programs.

Results: There was a significant relationship detected between MDSPSP and skin, nail, throat, mouth and weight complaints, sleeplessness, anxiety and pessimistic feeling.

Conclusion: In this study, although social support was associated with chemotherapy-related symptoms (throat and mouth, skin and nails and feeling of tension), there was no significant relationship

\section{ÖZ}

Amaç: Kanser tedavilerinden biri olan kemoterapinin neler getireceği konusunda hastalar belirsizlik ve korku yaşamaktadırlar. $\mathrm{Bu}$ belirsizlik ve korku, sıklıkla hastaların sosyal destek gereksinimini artırmaktadır. Sosyal desteğin, aile, arkadaş yada sağlık personelinden gelmiş olması önemsenmeksizin, kemoterapiyle daha etkin baş etmede önemli rol oynadığı düşünülmektedir. Sosyal destek, kemoterapinin semptomları gibi olumsuz durumlara karşı bir tampon işlevi görmektedir. Sosyal destek, kemoterapinin neden olduğu stres ile başa çıkmasına ve bunun yanı sıra yaşam kalitelerini de artırmaya yardımcı olmaktadır. Araştırma, jinekolojik kanserli kadınlarda algılanan sosyal destek düzeyleri ve kemoterapi semptomları arasındaki ilişkinin belirlenmesi amacıyla yapılmıştır.

Yöntemler: Çalışma tanımlayıcı olarak planlandı. Örneklem, iki devlet hastanesine başvuran 148 hastayı içermektedir. Veriler Kemoterapi Semptom Değerlendirme Ölçeği, Çok Boyutlu Algılanan Sosyal Destek Ölçeği (ÇBASD) ve bir tanımlayıcı özellikler formu kullanılarak toplanmıştır. Veriler SPSS yazılım programları kullanılarak analiz edilmiştir.

Bulgular: Deri ve tırnaklar, ağız, boğaz, kilo, uyuma güçlüğü, endişeli veya sıkıntılı hissetme, karamsar veya üzüntülü hissetme ile ilgili problemler ile ÇBASD ölçeği arasında anlamlı bir ilişki bulunmuştur $(\mathrm{p}<0,05)$.

Sonuç: Bu çalışmada sosyal desteğin kemoterapiye ilişkin bazı semptomlar (boğaz ve ağız, deri ve tırnaklar ve gerginlik hissi) ile anlamlı ilişkisi bulunurken, bazı semptomları (nefes darlığı, ishal,

Address for Correspondence: Sakine YILMAZ, Çankırı Karatekin University Faculty of Health Science,

Received: 25.10 .2019

Çankırı, Turkey

E-mail: sakinee_yilmaz@hotmail.com ORCID ID: orcid.org/0000-0002-7406-1389

Accepted: 24.04.2020

Cite this article as: Yılmaz S, Vural G. Determining the Relationship between Perceived Social Support Levels and Chemotherapy Symptoms in Women with Gynaecological Cancer. Bezmialem Science 2021;9(3):326-33. 
with other symptoms (shortness of breath, diarrhoea, constipation, infection signs, alopecia and numbness in the hands or feet). It was concluded that social support status was an important factor for experiencing physical and psychological symptoms in Turkey.

Keywords: Gynaecological cancers, social support, chemotherapy kabızlık, enfeksiyon belirtileri, alopesi, ellerde veya ayaklarda uyuşma) etkilemediği saptanmıştır. Sosyal destek durumunun ülkemizde kanser hastalarında fiziksel ve psikolojik semptom yaşamada önemli bir faktör olduğu sonucuna varılmıştır.

Anahtar Sözcükler: Jinekolojik kanserler, sosyal destek, kemoterapi

\section{Introduction}

Gynaecological cancers constitute $18 \%$ of cancers diagnosed in women (1). According to Pinar et al. (2), 16\% of women die because of cancer-related reasons, and gynaecological cancer comes after breast cancer with the highest global mortality rates associated with cancer. In 2015, the American Cancer Society reported that among women, endometrial cancer ranked fourth as the most frequently diagnosed cancer and ovarian cancer accounted for $5 \%$ of cancer deaths (3). Similarly, the Department of Cancer Control announced that endometrial, ovarian and cervical cancers ranked fourth, seventh and ninth, respectively, as the most frequently diagnosed cancers in women in Turkey in 2014 (4).

Today, the nature of cancer is well understood, and treatment methods are developing rapidly. However, the toxic side effects of treatment are commonly seen. Although the positive effects of chemotherapy, such as increasing the life expectancy of patients, are known, it also has toxic qualities that cause undesirable side effects, including nausea, vomiting, loss of appetite and hair loss (5-7). Additionally, Bektaş and Akdemir (8) reported that patients who receive chemotherapy show depression and anxiety disorders that cause difficulties in coping with chemotherapy. The quality of life of patients is affected by disturbances in physical, emotional, social and economic status. Decreased quality of life increases the occurrences of depression, anxiety and social isolation, as well as similar psychological issues (9). Social support from family members, relatives and peers, in addition to others in the social circle, should be available to individuals who go through hardships or feel tense (10-13). Social support is known to influence physical and mental well-being and adaptation to cancer. Social support decreases harmful influences of negative life events on physical and mental well-being by buffering the individual and his or her stress. It also protects individuals from the negative effects of stress and is crucial for supplying a sense of belonging and self-esteem and helping them regain their health and feel good $(14,15)$. Sufficient social support and coping with the psychological, social and mental problems associated with gynaecological cancer require additional supportive approaches to treatment and care $(16,17)$. As a result, social support, regardless of whether it is provided by family, peers or medical staff, is crucial for effectively coping with cancer and its treatment. Although there are many studies on chemotherapy and its symptoms in the field of nursing, there are a limited number of studies that determine the relationship between chemotherapy symptoms and social support. In our country, no study has determined the relationship between chemotherapy symptoms and social support in gynaecological cancers. In this respect, the results of the study are valuable, and it is anticipated to make an important contribution to the nursing literature.

In addition to systematically evaluating the side effects of women with gynaecological cancer, social and psychological needs should also be considered. Nurses who care for cancer patients should be aware of the psychosocial needs of patients in addition to their physical needs and follow collaborative approaches that aim to adequately meet patients' needs.

This research aimed to determine the relationship between perceived social support levels and chemotherapy symptoms in women with gynaecological cancer and advise medical staff in future consultations.

\section{Methods}

\section{Design and Setting}

This descriptive design study was conducted at the outpatient chemotherapy unit of two public hospitals in Ankara. This research aimed to determine the relationship between perceived social support levels and chemotherapy symptoms in women with gynaecological cancer. The total population in the two public hospitals consisted of 605 patients with gynaecological cancer who received chemotherapy in 2008.

\section{Sample Size}

The following formula was used to determine the sample size for the research: the number of questions in the scales $\mathrm{x}$ number of answer options. For the Multidimensional Scale of Perceived Social Support (MDSPSP) and Chemotherapy Symptom Assessment Scale (C-SAS), 84 (12 questions x 7 answer options) and 96 (24 questions x 4 answer options) patients, respectively, were identified as the maximum number of patients among the sample sizes calculated. The C-SAS scale had 24 questions with four multiple options each and was thus equal to 96 patients. It is envisaged to include at least 1.5 times the number of patients determined for the sample size. The total sample size was calculated as follows: 96x1.5=144 patients (6). Quota sampling method was applied for sample selection, and voluntary sampling was conducted.

\section{Participants and Procedures}

Participants were 148 patients who were admitted to the two public hospitals in 2010. Participants were native Turkishspeaking patients who were diagnosed with non-metastatic gynaecological cancer and were receiving chemotherapy for the first time. Moreover, they have taken chemotherapy four times over time and had undergone a surgical procedure. All patients 
were at least 18 years old and volunteered to participate. The study excluded patients who were disabled or had hearing, communication or psychiatric problems.

\section{Research Question}

What is the relationship of perceived social support on chemotherapy side effects?

\section{Instruments}

Data were collected using C-SAS, MDSPSP and a descriptive feature form developed by the researchers.

A descriptive feature form was used to gather sociodemographic information (age, education, marital status, living arrangements, income rate, residence area (village, town or city), position relative to the hospital (in the same place or not), transportation from and to the hospital, health insurance and job) and disease characteristics of the patients (diagnosis, disease duration, knowledge about the disease, information on drug treatment, experiencing treatment-related problems, taken preventions against the symptoms or not, someone supporting during illness and who was the most supportive during illness).

MDSPSP was developed to measure perceived social support (18). The scale's reliability and validity for use in Turkey were established by Eker et al. (18) in 2001. The highest and lowest scores that can be earned on the scale are 84 and 12, respectively. Higher scores indicate that there is relatively more social support (18). The revised MDSPSP of Eker, Arkar and Yaldız (18) was internally consistent, with a Cronbach's alpha of 0.92.

C-SAS was developed in England where its validity and reliability were initially established (19). In Turkey, a similar investigation was conducted by Aslan et al. (6) in 2003. Scores increased with the intensity and severity of symptoms. The Cronbach's alpha values for the internal consistency of the three C-SAS subscales are as follows: frequency of symptoms $(\alpha=0.67)$, intensity of symptoms $(\alpha=0.80)$ and severity of symptoms $(\alpha=0.82)$ (6).

\section{The Implementation of Data Collection Tools}

The researcher introduced herself before starting the data collection and gave information about the purpose of the research to the cancer patients. Data collection tools were applied during a face-to-face session by the researcher. Interviews to collect data lasted for just about ten min.

\section{Statistical Analyses}

Data collected through questionnaires and scales were transferred to a computer. The appropriateness of the normal distribution of scale scores was analysed using the Shapiro-Wilk test. All scores were not normally distributed. Number and percentage were used for categorical data and median and interquartile range for scale scores. MDSPSP scores were presented as mean \pm standard deviation. Relationship between diagnosis and some patient information were investigated using the chi-square test. The relationship between the two scale scores were analysed using the Spearman rank correlation coefficient. MS Excel 2003 and SPSS for Windows version 15.0 package programme were used for all statistical analyses and calculations. A p value of $<0.05$ was considered to be statistically significant.

\section{Ethical Issues}

Before completing the questionnaires, the participants gave their consent in written form. Patients were under no obligation, financial or otherwise, to participate. Ethical approval was provided by the clinical research ethics committee in Ankara, and written approval was received from the surgeon generals of two public hospitals (B.10.4.1SM.4.06.00.22/2933 and B.10.4.1SM.4.06.00.09/773).

\section{Results}

\section{Sociodemographic Characteristics}

The mean age of the participants was $52.7 \pm 7.8$ years. Of participants, $75 \%$ were married, $49.3 \%$ lived with their husbands and children, $42.5 \%$ did not have any education and $81.8 \%$ had medium-sized incomes. Furthermore, 68.3\% lived in urban areas and $90.5 \%$ had social insurance (Table 1).

\section{Distribution of Women's Cancer and Some of the Properties of Chemotherapy}

In this study, $52.7 \%$ of participants were receiving chemotherapy four times, and $62.8 \%$ were diagnosed with ovarian cancer. Of participants, $77.7 \%$ declared that they had been informed about their disease. About two-thirds (67.6\%) had been informed about chemotherapy medicines, and $66.2 \%$ had been informed about the possible side effects of medicines. Of participants, $55.4 \%$ had no prior history of discomfort with chemotherapy, whereas $81.8 \%$ of those who had previous discomfort were taking precautions (breathing exercise, regular diet, using herbal tea and some herbal foods, using a wig or hat, etc.). More than half $(52.7 \%)$ of the sample reported that their husbands gave the maximum amount of social support, and $97.3 \%$ of the participants had at least one individual providing social support during the process (Table 2).

\section{The Relationship Between Perceived Social Support and Chemotherapy Side Effects}

Surprisingly, there was a significant positive correlation between social support from the family and skin- and nail-related problems such as dryness and itchiness $(r=0.442, p=0.045)$, indicating that those with high social support from their family experienced more problems with their skin and nails. However, a weak positive correlation was observed between social support from a special person and throat- and mouth-related problems $(\mathrm{r}=0.38, \mathrm{p}=0.024)$. Furthermore, there was a weak negative correlation between social support from a special person and weight changes $(r=-0.254, \mathrm{p}=0.026$; Table 3$)$.

There was a weak positive correlation between social support from a special person and total average score $(r=0.393, p=0.002)$ as well as falling asleep difficulties $(\mathrm{r}=0.362, \mathrm{p}=0.005)$. Perhaps patients who had falling asleep difficulties eventually got more social support from a special person, as reflected by their higher total social support score. Also, a weak significant positive 
Table 1. Distribution of sociodemographic characteristics of patients $(n=148)$

\begin{tabular}{|c|c|c|}
\hline Sociodemographic characteristics & $\mathrm{n}$ & $\%$ \\
\hline \multicolumn{3}{|l|}{ Age (years) } \\
\hline 49 and below & 51 & 34.5 \\
\hline $50-55$ & 35 & 23.6 \\
\hline 56 and above & 62 & 41.9 \\
\hline \multicolumn{3}{|l|}{ Marital status } \\
\hline Married & 111 & 75.0 \\
\hline Not married* & 37 & 25.0 \\
\hline \multicolumn{3}{|l|}{ Education status } \\
\hline Illiterate & 40 & 27.0 \\
\hline Literate & 23 & 15.5 \\
\hline Primary school & 47 & 31.8 \\
\hline Middle school & 10 & 6.8 \\
\hline High school and older & 28 & 18.9 \\
\hline \multicolumn{3}{|l|}{ People who live together } \\
\hline Alone & 14 & 9.5 \\
\hline Spouse and children & 73 & 49.3 \\
\hline Other (brother/sister, friend, relative, etc.) & 61 & 41.2 \\
\hline \multicolumn{3}{|l|}{ Income rate } \\
\hline Good & 11 & 7.4 \\
\hline Middle & 121 & 81.8 \\
\hline Low & 16 & 10.8 \\
\hline \multicolumn{3}{|l|}{ Area of residence } \\
\hline Rural & 47 & 31.7 \\
\hline Urban & 101 & 68.3 \\
\hline \multicolumn{3}{|l|}{ Social security } \\
\hline Yes & 134 & 90.5 \\
\hline No & 14 & 9.5 \\
\hline \multicolumn{3}{|l|}{ Job } \\
\hline Officer & 4 & 2.7 \\
\hline Working at home (housewife) & 118 & 79.7 \\
\hline Retired & 12 & 8.1 \\
\hline Farmer & 9 & 6.1 \\
\hline Other (self-employed, worker, unemployed, etc.) & 5 & 3.4 \\
\hline
\end{tabular}

correlation indicated that patients who reported greater feelings of tension or anxiety on the C-SAS also had higher MDSPSP scores from family $(r=0.261, \mathrm{p}=0.016)$ and friends $(\mathrm{r}=0.288$, $\mathrm{p}=0.008)$ as well as a higher total score. A similar positive correlation was also found between pessimism and upset on the C-SAS and social support. Specifically, patients who experienced pessimism and upset received more social support from family $(\mathrm{r}=0.222, \mathrm{p}=0.048)$ and friends $(\mathrm{r}=0.285, \mathrm{p}=0.010)$ and also had higher overall total scores on the MDSPSP $(r=0.349, p=0.002$; Table 4).
Table 2. Distribution of patients' diseases and chemotherapy-related properties $(n=148)$

Properties of diseases and chemotherapy $\quad n \quad \%$

\section{Number of cures}

5

6

\begin{tabular}{|l|l|}
\hline 78 & 52.7 \\
\hline 29 & 19.6 \\
\hline 41 & 27.7 \\
\hline
\end{tabular}

Cancer types

Endometrial cancer

\begin{tabular}{l|l}
30 & 20.3
\end{tabular}

Ovarian cancer 93

Others*

Information on the disease

\begin{tabular}{|c|c|c|}
\hline $\begin{array}{l}\text { Received } \\
\text { Did not receive }\end{array}$ & $\begin{array}{l}115 \\
33\end{array}$ & $\begin{array}{l}77.7 \\
22.3\end{array}$ \\
\hline \multicolumn{3}{|c|}{ Information on medicines of chemotherapy } \\
\hline Received & 100 & 67.6 \\
\hline Did not receive & 48 & 32.4 \\
\hline
\end{tabular}

Information on possible side effects of medicines involved

Received

\begin{tabular}{l|l}
98 & 66.2
\end{tabular}

Did not receive

50

33.8

Any history of disturbances with former cures of chemotherapy

Present

\begin{tabular}{l|l}
66 & 44.6
\end{tabular}

Absent

82

55.4

Precautions for possible side effects $(n=66$ )

Taken

Not taken

\begin{tabular}{l|l}
54 & 81.8
\end{tabular}

Social support source

Yes

\begin{tabular}{|l|l|}
\hline 144 & 97.3 \\
\hline 4 & 2.7 \\
\hline
\end{tabular}

No

Supporting individuals $(n=144)$ **

Partner

Sister/brother

78

52.7

Friend

22

14.9

Friend

5

3.4

Child

77

52.0

Others (relatives, neighbours, etc.)

15

10.1

Total

197

130.4

*Cervical cancer ( $n=23)$, vaginal cancer $(n=1)$ and uterine tubal cancer $(n=1)$

**Since it can be more than one supporter, $n$ folded. 
Additionally, there was no statistically significant relationship between the other C-SAS symptoms and MDSPSP subgroups or total scores ( $p>0.05$; Tables 3 and 4).

\section{Discussion}

In this study, $77.7 \%$ of our patients were knowledgeable of their disease. It was determined that $67.6 \%$ of the patients had knowledge about chemotherapy, $66.2 \%$ knew the side effects of chemotherapy and $44.6 \%$ had previously experienced problems in chemotherapy treatment (Table 2). According to the research of Pinar et al. (20), patients who receive information about their treatment have a higher quality of life and better overall well-being. The study of Özyurt (14) reported that $41 \%$ of the patients' emphasised that being informed was beneficial. Having knowledge about chemotherapy and knowing what to do and how to deal with any problems can provide comfort to patients. In our study, $18.2 \%$ of patients who experienced chemotherapy side effects did not take precautions, whereas $81.8 \%$ took precautions (Table 2). According to the research of Kayış (21), 11.1\% of the patients who experienced chemotherapy side effects did not take precautions, and $68.9 \%$ took precautions. These results show that the majority of patients receiving chemotherapy take precautions against the side effects of treatment. However, when the proportion of patients not taking precautions was examined, the result suggested that some patients are not adequately helped to deal with side effects or the nursing services provided to these patients are not used effectively. It is thought that nurses should give more consultancy support to patients who do not take precautions.

\section{Table 3. Co-relation between MDSPSP subgroups and C-SAS score}

\begin{tabular}{|c|c|c|c|c|c|c|c|c|}
\hline \multirow{3}{*}{ Physical symptoms of C-SAS } & \multicolumn{8}{|c|}{ MDSPSP subgroups } \\
\hline & \multicolumn{2}{|l|}{ Family } & \multicolumn{2}{|l|}{ Peers } & \multicolumn{2}{|c|}{ Special person } & \multicolumn{2}{|c|}{ Sum of the scale } \\
\hline & r & $\mathrm{p}$ & r & $\mathrm{p}$ & r & $\mathrm{p}$ & r & $\mathrm{p}$ \\
\hline Nausea after the treatment & 0.010 & 0.922 & 0.180 & 0.078 & 0.037 & 0.716 & 0.156 & 0.127 \\
\hline Vomiting after the treatment & -0.053 & 0.697 & 0.082 & 0.542 & -0.080 & 0.554 & 0.019 & 0.890 \\
\hline Aches & 0.120 & 0.309 & -0.136 & 0.249 & -0.090 & 0.443 & -0.102 & 0.386 \\
\hline Shortness of breath & -0.325 & 0.162 & -0.152 & 0.521 & -0.096 & 0.689 & -0.136 & 0.568 \\
\hline Infection (fever, flu-like symptoms, etc.) & 0.251 & 0.146 & 0.132 & 0.451 & 0.156 & 0.371 & 0.156 & 0.371 \\
\hline $\begin{array}{l}\text { Sensation of pricking and lethargy in hands } \\
\text { and feet }\end{array}$ & -0.011 & 0.910 & -0.034 & 0.732 & -0.048 & 0.631 & -0.043 & 0.668 \\
\hline $\begin{array}{l}\text { Problems of throat and mouth (sensitivity or } \\
\text { dryness) }\end{array}$ & 0.141 & 0.419 & 0.191 & 0.272 & 0.381 & 0.024 & 0.284 & 0.098 \\
\hline Change in appetite & 0.205 & 0.061 & 0.122 & 0.270 & 0.050 & 0.648 & 0.180 & 0.102 \\
\hline Weight loss or gain & 0.030 & 0.792 & -0.070 & 0.543 & -0.254 & 0.026 & -0.110 & 0.341 \\
\hline $\begin{array}{l}\text { Problems of eyes (itchiness, sensitivity or } \\
\text { dryness, etc.) }\end{array}$ & 0.369 & 0.175 & 0.191 & 0.496 & 0.169 & 0.547 & 0.359 & 0.189 \\
\hline Sense of weakness & 0.141 & 0.102 & 0.127 & 0.140 & 0.057 & 0.506 & 0.118 & 0.173 \\
\hline Sense of unusual exhaustion & 0.061 & 0.498 & 0.081 & 0.372 & 0.003 & 0.974 & 0.026 & 0.771 \\
\hline
\end{tabular}

MDSPSP: Multidimensional scale of perceived social support, C-SAS: Chemotherapy symptom assessment scale

Table 4. Co-relation between MDSPSP subgroups and C-SAS score

\begin{tabular}{|c|c|c|c|c|c|c|c|c|}
\hline \multirow{3}{*}{ Psychosocial symptoms of C-SAS } & \multicolumn{8}{|c|}{ MDSPSP subgroups } \\
\hline & \multicolumn{2}{|l|}{ Family } & \multicolumn{2}{|l|}{ Peers } & \multicolumn{2}{|c|}{ Special person } & \multicolumn{2}{|c|}{ Sum of the scale } \\
\hline & r & $\mathrm{p}$ & r & $\mathrm{p}$ & $r$ & $p$ & $r$ & $p$ \\
\hline Feeling anxious or tense & 0.261 & 0.016 & 0.288 & 0.008 & 0.105 & 0.343 & 0.305 & 0.005 \\
\hline
\end{tabular}


Additionally, more than half of the sample (52.7\%) reported that their husbands gave the maximum amount of social support (Table 2). According to the prosecutor's report, the support required by the individual is primarily provided by their immediate surroundings. Dansuk et al. (22) found that women receive more social support from their husbands and children than from any other group of social support providers. Further, Tel and Tel (23) found that women receive more social support from their families than from any other group of social support providers. However, Sammarco and Konecny's (24) research indicated that patients receive social support in the following order: from friends, family and health staff. According to Ayaz et al. (17), women need support from family, friends and medical staff during their treatment as the diagnosis of cancer, duration of treatment and obscurity of the disease cause social isolation. Social support serves to decrease cancer patients' anxiety, helps them cope with the disease and provides positive influences on their quality of life. Although social support could not eliminate the condition completely, it helps patients adapt to chronic physical or psychological conditions and has a positive influence on their mood and abilities to cope with the disease $(25,26)$.

A significant positive correlation was found between social support degree provided by family members on the MDSPSP and skin- and nail-related problems $(\mathrm{p}=0.045$; Table 3$)$. It is thought that patients with physical appearance problems may be offered more social support than their families. There was also a statistically significant relationship, although it is weak $(\mathrm{p}=0.024)$, between social support degree provided by a special person on the MDSPSP and mouth- or throat-related problems (Table 3). As a consequence of the higher discomfort level associated with such symptoms, patients may get more support from "a special person" who can be a romantic interest, neighbour or family relative. In addition, throat- and mouth-related problems attract more attention because they cause pain and disability in speaking or prevent proper nourishment, which can further wear patients down. Therefore, under these conditions, it is possible that such patients would receive more support from their special person. Also, chemotherapy is highly likely to cause changes in the physical appearance of patients. Such changes are especially depressing for women. Consequently, some women develop more intimate bonds with their social support givers during treatment, whereas others withdraw from communication. MDSPSP scores and changes were significantly negatively correlated ( $\mathrm{p}=0.026$; Table 3). Patients who received less social support had more difficulties with weight. Chemotherapy treatment takes a long time, and there are many symptoms in this process. The long duration of physical symptoms can cause psychosocial problems (25). Therefore, social support is needed to cope with these problems. Social support may sometimes positively and sometimes negatively affect symptoms in this process. As a result, it is possible to expect a better perception of physical health (physical symptoms) in the long term by better understanding of psychological health and quality of life. According to Rustøen and Begnum (27), patients with breast cancer need psychological support and psychological improvements help make the physical condition more positive.
There is some evidence that social support is associated with the physical and psychological adjustment of cancer patients to the disease, but a detailed study on these issues could not be reached in the literature review. We can say that there is a need for studies that determine the relationship between perceived social support and side effects seen in patients receiving chemotherapy.

As can be seen in Table 4, there is a weak significant positive correlation between support degree from a special person and both sleeping difficulties and total MDSPSP scores ( $\mathrm{p}=0.002$ and 0.005 , respectively). Quality of life is highly related to sleeping. Göktalay et al. (28) noted that symptoms of chemotherapy influence the quality of life of patients no matter the intensity of symptoms (pain, fatigue, etc.). Although patients receive social support from their social circles, they still face sleeping difficulties. Even if the social supports cannot remove the stressful situation, they facilitate the adaptation to situation related to physical and psychological health, create positive moral effects and help patients cope with these problems (25). Studies have shown that many psychological methods, such as providing social support, are effective in reducing emotional (difficulty sleeping and stress) and physical symptoms (fatigue, pain, nausea and vomiting and taste change) associated with cancer treatment and enhancing coping skills $(29,30)$.

Beser and $\mathrm{Öz}_{\mathrm{z}}$ (31) pointed out that living with cancer involves learning how to cope with cancer symptoms, dealing with its influences on life and reorganising one's life for a new life standard. Since the course is long and full of side effects, patients may experience hopelessness, despair, anticipation of the worst, social isolation, depression or a sense of exhaustion. Our research indicated an increase in the total scores of MDSPSP $(\mathrm{p}=0.005)$ and its subgroups, family $(\mathrm{p}=0.016)$ and friends $(\mathrm{p}=0.008)$, as well as of the feelings of tension and anxiety on the C-SAS. Similar significant positive correlations were also observed between scores representing support provided by the family $(\mathrm{p}=0.048)$ and friends $(\mathrm{p}=0.010)$ and total MDSPSP scores $(\mathrm{p}=0.002)$ and feelings of pessimism or upset on the C-SAS (Table 4). These correlations were positive but weak. Karabulutlu et al. (32) supported the belief that cancer patients cope with the anxiety, depression and other negative emotions caused by their disease with help from their families and friends. Özdemir et al. (33) acknowledged that patients received $70 \%$ of social support from their spouses or children. The social support that patients need to cope with their condition should contribute to their self-esteem and self-confidence and make them feel secure. Unfortunately, social support occasionally conflicts with patients' self-esteem. As a consequence, patients feel insecure about themselves.

There is no statistically significant correlation between other subgroups or MDSPSP total score and C-SAS symptoms ( $>0.05$; Tables 3, 4). There are many side effects (nausea, vomiting, weakness, insomnia, anxiety, depression and the like) and therapeutic effects of chemotherapy, and these problems are the daily lives of patients functioning in the negative direction. The long duration of physical symptoms causes psychosocial problems. Thus, physical and psychosocial symptoms lead to an increase in patients' social support needs $(25,34)$. In 
Turkey, social support is often emphasised in patients receiving chemotherapy, and the findings of research on this subject are insufficient. Therefore, our study focuses on whether there is a relationship between chemotherapy-related symptoms and social support status patients perceive.

\section{Conlusion}

In conclusion, despite the limitations caused by the diseases and treatment methods, some important goals of health services have begun to include helping patients feel good, increase healthcare skills, maintaining daily life activities and adapting to the planned treatment programmes. In this regard, nurses as healthcare professionals have great responsibilities. This research showed that patients perceive social support in accordance with the intensity of their symptoms during treatment. The relation is very probably influenced by different cancer types or treatment and symptoms that each patient experiences. To take precautions against symptoms, discovering their causes and frequencies is essential. As a consequence, adaptation to treatment gets easier and patients' quality of life increases. Nurses who spend time with patients during the treatment have a significant responsibility since they also spend time with patients' family and friends.

Furthermore, a detailed study on these issues could not be reached in the literature review. There is a need for studies that determine the relationship between perceived social support and side effects seen in patients receiving chemotherapy. This research consisted of women without hearing or visual impairments who were at least 18 years old and were fluent speakers. It is possible to conduct a similar research without limiting the sample to Turkish speakers or those without visual or hearing defects.

\section{Ethics}

Ethics Committee Approval: Ethical approval was provided by the clinical research ethics committee in Ankara, and written approval was received from the surgeon generals of two public hospitals (B.10.4.1SM.4.06.00.22/2933 and B.10.4.1SM.4.06.00.09/773).

Informed Consent: Before completing the questionnaires, the participants gave their consent in written form.

Peer-review: Externally peer reviewed.

\section{Authorship Contributions}

Concept: G.V., S.Y., Design: G.V., S.Y., Data Collection or Processing: G.V., S.Y., Analysis or Interpretation: G.V., S.Y., Literature Search: G.V., S.Y., Writing: G.V., S.Y.

Conflict of Interest: No conflict of interest was declared by the authors.

Financial Disclosure: The authors declared that this study received no financial support.

\section{References}

1. Gonçalves V. Long-term quality of life in gynecological cancer survivors. Curr Opin Obstet Gynecol 2010;22:30-5.
2. Pinar G, Kaplan S, Akalin A, Abay H, Ayhan A, Ayhan Y. Evaluation of Sexual Dysfunction and Affecting Factors in Turkish Women with Gynecological Cancer. Sex Disabil 2016;34:49-62.

3. American Cancer Society Cancer facts \& figures. 2015. [Cited 2015 Nov 8]. Available from: http://www.cancer.org

4. T.C. Ministry of Health, the Department of Cancer Control. 2014. [Cited 2018 Jan 6]. Available from: http://kanser.gov.tr.

5. Usta Yeşilbalkan Ö, Durmaz Akyol A, Çetinkaya Y, Altın T, Ünlü D. Studying the symptoms that are being experienced due to treatment by the patients who receive chemotherapy end their effects on the quality of life. Ege University Journal of School of Nursing 2005;21:13-31.

6. Aslan Ö, Vural H, Kömürcü Ş, Özet A. Effect of Education On Chemotherapy Symptoms in Cancer Patients Receiving Chemotherapy. Cumhuriyet University Journal of School of Nursing 2006;10:15-28.

7. Kayl AE, Meyers CA. Side-effects of chemotherapy and quality of life in ovarian and breast cancer patients. Curr Opin Obstet Gynecol 2006;18:24-8.

8. Bektaş HA, Akdemir N. The assessment of functional status in individual 's who have cancer. Turk J Med Sci 2006;26:488-99.

9. Çam $O$, Gümüş BA. Emotional support focused nursing interventions for the women with breast. Cumhuriyet University Journal of School of Nursing 2006;10:52-60.

10. Hann D, Baker F, Denniston M, Gesme D, Reding D, Flynn T, et al. The influence of social support on depressive symptoms in cancer patients: age and gender differences. J Psychosom Res 2002;52:27983.

11. Parker PA, Baile WF, de Moor Cd, Cohen L. Psychosocial and demographic predictors of quality of life in a large sample of cancer patients. Psychooncology 2003;12:183-93.

12. Aksüllü N, Doğan S. Relationship of social support and depression in institutionalized and non-institutionalized elderly. Anadolu Journal of Psychiatry 2004;5:76-84.

13. Ashing-Giwa KT, Padilla G, Tejero J, Kraemer J, Wright K, Coscarelli A, et al. Understanding the breast cancer experience of women: a qualitative study of African American, Asian American, Latina and Caucasian cancer survivors. Psychooncology 2004;13:408-28.

14. Özyurt BEA. Descriptive study about social support Percieved by cancer patients. Journal of Kriz 2007:15;1-15.

15. Tan M. Social support and coping in Turkish patients with cancer. Cancer Nurs 2007;30:498-504.

16. Tan M, Karabulutlu E. Social support and hopelessness in Turkish patients with cancer. Cancer Nurs 2005;28:236-40.

17. Ayaz S, Efe Ş, Korukluoğlu S. Level of perceived social support of patients with gynecological cancer and affecting factors. J Med Sci 2008;28:880-5.

18. Eker D, Arkar H, Yaldız H. Actorial structure, validity, and reliability of revised form of the Multidimensional Scale of Perceived Social Support. Turkish Journal of Psychiatry 2001;12:17-25.

19. Brown V, Sitzia J, Richardson A, Hughes J, Hannon H, Oakley C. The development of the Chemotherapy Symptom Assessment Scale 
(C-SAS): a scale for the routine clinical assessment of the symptom experiences of patients receiving cytotoxic chemotherapy. Int J Nurs Stud 2001;38:497-510.

20. Pınar G, Cezayir L, Doğan N, Kaya N. Determination of the Risk Factors in Individuals with Gynecological Cancer. International Journal of Hematology and Oncology 2008;18:208-16.

21. Kayış A. Cancer Patients' Perception of Disease and Hopelessness Levels. Master Thesis. Istanbul: Haliç Univ. 2009.

22. Dansuk R, Ağargün M, A Kars B, Pars Ağargün H, Turan C, Ünal O. Evaluation of the Psychosocial Characteristics of Gyneacologic Cancer Patients. T Clin Gyneacol Obs 2002: 12; 142-7.

23. Tel H, Tel H. Quality of life and social support in Hemodialysis patients. Pak J Med Sci 2011;27:64-7.

24. Sammarco A, Konecny LM. Quality of life, social support, and uncertainty among Latina and Caucasian breast cancer survivors: a comparative study. Oncol Nurs Forum 2010;37:93-9.

25. Bertöre CM. Types and sources of social support for people afflicted with cancer. Nursing and Health Sciences 2000;2:93-101.

26. Allen SM, Ciambrone D, Welch LC. Stage of life course and social support as a mediator of mood state among persons with disability. J Aging Health 2000;12:318-41.

27. Rustøen T, Begnum S. Quality of life in women with breast cancer: a review of the literature and implications for nursing practice. Cancer Nurs 2000;23:416-21.
28. Göktalay T, Akın M, Aydemir Ö. Quality of life evaluation in patients with lung cancer. Journal of Respiratory Diseases 2001;13:265-70.

29. Golant M, Altman T, Martin C. Managing cancer side effects to improve quality of life: a cancer psychoeducation program. Cancer Nurs 2003;26:37-44.

30. Williams SA, Schreier AM. The effect of education in managing side effects in women receiving chemotherapy for treatment of breast cancer. Oncol Nurs Forum 2004;31:16-23.

31. Beser N, Öz F. Anxiety- Depression levels and quality of life of patients with lymphoma who are curing. Cumhuriyet University Journal of School of Nursing 2003;7:47-58.

32. Karabulutlu EY, Bilici M, Çayır K, Tekin SB, Kantarcı R. Coping, anxiety and depression in Turkish patients with cancer. Eur J Gen Med 2010;7:296-302.

33. Özdemir S, Öner DF, Atkovar G, Özbek Ö, Özmen M. Psychosocial characteristics of patients undergoing radiotherapy and their expectations of their radiation oncologist. Türkish Journal of Oncology 2011;26:12-7.

34. Arslan S, Akın B, Koçoğlu D. The relationship between perceived social support, perceived socio -demographic characteristics and symptoms related to chemotherapy treatment in the patients who are receiving chemotherapy. Hemarge 2008:47-56. 